\author{
I.A. Rodionova \\ Peoples’ Friendship University of Russia (RUDN University), Russia, Moscow \\ e-mail: iarodionov@mail.ru
}

\title{
GLOBAL INDUSTRIAL DEVELOPMENT TRENDS: DYNAMICS AND REGIONAL ASPECTS
}

The article analyzes changes in the spatial structure of world industry (including high-tech) at the global and regional level in dynamics. The processes in the mining and manufacturing industries of the world are characterized. The article also presents the author's rating of countries by the level of industrial development during the transition to a post-industrial economy based on a matrix of data on 4 indicators of the level of development of the manufacturing industry in 117 countries of the world.

The calculations were carried out on the basis of official sources of information from the World Bank, UNIDO, the US Science Foundation, etc.

It is shown that at present the rating of the most industrial regions of the world is headed by Asia. The world industry leaders are China, the United States and other developed countries, as well as some developing countries in Asia and Latin America. It is shown that the fragmentation of industrial production in the context of globalization contributed to the spread of new technologies and the development of the industrialization process in the world. In the group of leaders in the author's rating are mainly developed countries. But there is a shift in industrial development towards a group of developing countries. At the same time, the process of differentiation of developing countries is recorded. Although a significant part of developing countries (especially African countries) still represent the "deep periphery" of the world industry. It was concluded that the global "industrial landscape" in the context of the transition to the digital economy and in the context of the COVID19 pandemic will change.

Key words: world, regions, industry, manufacturing industry, industrialization, regional shifts, knowledge and technology-intensive industries, ratings. JEL codes: L16, L60, O14, O57.

\author{
И.А. Родионова \\ Ресей халықтар достығы университеті (RUDN), Ресей, Мәскеу қ. \\ e-mail: larodionova@mail.ru
}

\section{Аүниежүзікік өндірістік даму тенденциямары: Аинамика және аймақтық аспектілер}

Мақалада әлемдік өнеркәсіптің кеңістіктік құрылымындағы (оның ішінде жоғары технологиялы) әлемдік және аймақтық, деңгейлегі динамикадағы өзгерістер талданады. Әлемлегі тау-кен және өңдеу өнеркәсібіндегі процестер сипатталады. Сондай-ақ, мақалада әлемнің 117 елінде өңдеу өнеркәсібінің даму деңгейінің 4 индикаторы туралы мәліметтер матрицасына негізделген постиндустриалды экономикаға көшу кезеңіндегі инАустриялық Ааму Аеңгейі бойынша елдердің авторлық рейтингі ұсынылған.

Есептеулер Аүниежүзілік банктің, ЮНИАО-ның, АҚШ-тың Ғылым қорының және т.б. ақпараттың ресми көздері негізінде жүргізілді.

Қазіргі уақытта әлемнің индустриалды аймақтарының рейтингін Азия басқарады. Әлемдік өнеркәсіптің көшбасшылары - Қытай, АҚШ және басқа дамыған елдер, сонымен қатар Азия мен Аатын Америкасындағы кейбір дамушы елдер. Жаһандану жағдайында өнеркәсіп өндірісінің бөлшектенуі әлемде жаңа технологиялардың таралуына және индустрияландыру процесінің дамуына ықпал еткені көрсетілген. Авторлық рейтингтегі көшбасшылар тобында негізінен дамыған елдер бар. Бірақ индустриялық дамуда дамушы елдер тобына қарай жылжу бар. Сонымен бірге дамушы елдердің дифференциациясы процесі жазылады. Аамушы елдердің (әсіресе Африка елдерінің) едәуір бөлігі әлі күнге Аейін әлемдік өнеркәсіптің «терең перифериясын» ұсынады. Сандық экономикаға көшу жағдайында және COVID19 пандемиясы жағдайында ғаламдық, «индустриялық мандшафт» өзгереді деген қорытынды жасалды.

Түйін сөздер: әлем, аймақтар, өнеркәсіп, өңдеу өнеркәсібі, индустрияландыру, аймақтық ауысулар, білімді және ғылымды қажет ететін өндірістер, рейтингтер. 


\title{
И.А. Родионова \\ Российский университет Аружбы народов (РУАН), Россия, г. Москва e-mail: iarodionova@mail.ru \\ Тенденции мирового промышкенного развития: динамика и регионамьные аспекты
}

\begin{abstract}
В статье анализируются изменения пространственной структуры мировой промышленности (в том числе высокотехнологичной) на глобальном и региональном уровнях в динамике. Охарактеризованы процессы в горнодобывающей и обрабатывающей промышленности мира. В статье также преАставлен авторский рейтинг стран по уровню промышленного развития при переходе к постиндустриальной экономике на основе матрицы данных по 4 показателям уровня развития обрабатывающей промышленности в 117 странах мира.

Расчеты проводились на основе официальных источников информации Всемирного банка, ЮНИАО, Научного фонда США и др.

Показано, что в настоящее время рейтинг самых индустриальных регионов мира возглавляет Азия. Аидерами мировой индустрии являются Китай, США и Аругие развитые страны, а также некоторые развивающиеся страны Азии и Аатинской Америки. Показано, что фрагментация промышленного производства в условиях глобализации способствовала распространению новых технологий и развитию процесса инАустриализации в мире. В группе ^илеров авторского рейтинга находятся преимущественно развитые страны. Но в промышленном развитии наблюдается сАвиг в сторону группы развивающихся стран. При этом фиксируется процесс дифференциации развивающихся стран. Хотя значительная часть развивающихся стран (особенно африканских) по-прежнему представляет собой «глубокую периферию» мировой индустрии. Был сАелан вывоА, что Глобальный «инАустриальный мандшафт» в контексте перехода к цифровой экономике и в контексте пандемии COVID19 изменится.
\end{abstract}

КАючевые слова: мир, регионы, промышленность, обрабатывающая промышленность, инАустриализация, региона^ьные сАвиги, наукоемкие и наукоемкие отрасли, рейтинги, JEL codes: L16, L60, O14, O57.

\section{Introduction}

Despite the transition of the world economy to post-industrialism and to a digital economy you can find more often in the scientific literature the statements on "rehabilitation of real economy sector", "re-industrialization", devaluation of "de-industrialization" term and even on a new definition of "postindustrial society" (Grinberg, 2016; Rodionova et al., 2016; Industrial Development...,2016; Ziolo, 2017; Kondrat'ev, 2017; Varnavsky, 2019). It is associated with further updating process of the industry ("neoindustrialization", "Industry 4.0", "Internet of Things") at the highly developed countries (Crescenzi \& Rodriguez-Pose, 2011; Draper, 2013; Tolkachev, 2015; Shvab, 2017; Gieranczyk \& Ryczkowski, 2018; Kokuytseva et al, 2019; Industrial Development..., 2020).

The increase in GDP is mainly achieved due to manufacturing and export-import of high-technology goods and services in modern economy (Gierańczyk, 2010; Rodionova et al., 2016; Digital Transformation .., 2017; Competitive Industrial..., 2020). A large number of scientific studies analyze the development processes of $R \& D$ in countries and, in particular, their implementation in practice, including at the major transnational companies (TNC)
(Yudina, 2009; Crescenzi \& Rodriguez-Pose, 2011; Kourtit et al., 2011; Kondrat'ev, 2017; Global Manufacturing..., 2016; Kilar, 2018; Competitive Industrial..., 2020; Industrial Development..., 2020). Many authors devote their works to the peculiarities of the development of industrial sector. They characterize the structural changes in the economy of certain countries and world regions. Experts of UNIDO (Industrial Development Report, Competitive Industrial Performance Index) reports show that the structural changes of the industrial branch is the main factor of the gross rate of the development productivity of this sphere (Global Manufacturing ..., 2016; Industrial..., 2016; Industrial..., 2020). But pursuant to its multiple-valued nature, the competitiveness serves as a more comprehensive characteristic of the economy development, than the current economic growth rate. The author of this article previously also attempted to classify countries by the level of their industrial development (Rodionova et al., 2016).

Therefore, the goal of this study is to analyze the contemporary industrialization process peculiarities in postindustrial transition and to reveal the differentiation of the regions and countries by the character and rates of the continuous industrialization process in the world. 


\section{Methodology}

The study of the world industry is distinguished by a number of important methodological features. The global industry is formed within a complex interaction of factors and the subordinate distribution of production capacities of many industries on the territory of countries and regions.

The study of structural changes in the world industry was carried out by six geographical regions: North America (the USA, Canada, Mexico); 2) Central and South America; Europe (Western and Eastern Europe, including the republics of the CIS); Asia; Africa; Oceania (including Australia).

It is worth noting that the data on industrial production of countries and regions was analyzed by physical terms: by volume or weight of manufactured products in dynamics since 1950. At the same time, the world leaders were compared by indicators at current prices (or at constant prices, 2015) in 2002-2019. The sources of the data of manufacturing value added are UNIDO and the US Science Foundation (at current prices, millions of current dollars) (Tables 1,2).

The authors' calculations gave an opportunity to analyze and characterize the changes in the shares of large regions in the global production of a particular industrial product (in mining and manufacturing industries) in dynamics. It was important to show, that regional structural shifts are the result of uneven changes intensity of analyzed indicators.
The collected base of the statistic data received from UNIDO, IMF, World Bank, OECD, World Intellectual Property Organization, UNESCO, US National Science Foundation and other international organizations allowed us to evaluate the positions of the countries. Respective author's classification of 117 world countries by four indexes of the innovative and industrial development were made up. Was used four indexes are: manufacturing value added (MVA) per capita, share of high technology export at the industrial export (\%); high technology export per capita; share of MVA in GDP (\%). The 117 countries were ranked by each criterion (from 1 to 117). The authors calculated also one specific index. It is the "relative industrialization level. It represents the share in creation of the manufacturing products against the share of the same country in the world population. All the indexes had equal "importance". The country ranks were summarized by each criterion in order to get the integrated index. Minimum values based on the ranks summary in the rating list were put in the leaders table and maximum - in the outsiders table, respectively.

\section{Results}

The situation in the global manufacturing industries. UNIDO data record a gap between the averages in developed and developing countries (Tabl. 1).

The following table presents data of the leaders of the global manufacturing industry in the period 2005-2019 (at constant prices 2015, US\$) (Table 2).

Table 1 - Per-capita MVA at constant 2015 prices in US\$

\begin{tabular}{|l|c|c|c|}
\hline Country group & 2005 & 2010 & 2018 \\
\hline World & 1332 & 1486 & 1770 \\
\hline Industrialized Economies & 4832 & 4878 & 5425 \\
\hline Developing \& Emerging Industrial Economies & 512 & 719 & 997 \\
\hline Emerging Industrial Economies (excl. China) & 525 & 593 & 683 \\
\hline China & 895 & 1622 & 2726 \\
\hline Other Developing Economies & 221 & 251 & 126 \\
\hline Least Developed Countries & 64 & 89 & 275 \\
\hline
\end{tabular}

Source: Industrial Statistics Database, 2020. UNIDO.

(https://stat.unido.org/app/country/W2.htm?Country=643\&Group=null ) 
Global industrial development trends: dynamics and regional aspects

Table 2 - The leaders of the world manufacturing industry in 2005 - 2019

\begin{tabular}{|c|c|c|c|c|}
\hline & \multicolumn{2}{|c|}{ Share of the world, \% } & \multicolumn{2}{c|}{ MVA per capita, US\$ } \\
\hline Country & 2005 & 2019 & 2005 & 2019 \\
\hline China & 13,69 & 29,67 & 895,2 & 2864,0 \\
\hline USA & 22,80 & 15,99 & 6727,9 & 6858,0 \\
\hline Japan & 9,47 & 7,01 & 6423,0 & 7645,0 \\
\hline Germany & 6,60 & 5,42 & 7043,3 & 8980,0 \\
\hline India & 1,73 & 3,11 & 131,0 & 314,9 \\
\hline Republic of Korea & 2,64 & 3,05 & 4722,1 & 8251,9 \\
\hline
\end{tabular}

Source: Industrial Statistics Database, 2020

Changes in the global industrial landscape continue. The positions of countries in the international ranking table are also changing. The total share of the 15 leaders of the manufacturing industry accounts for $80 \%$ of global production. In other words, the concentration of industrial production in the world is still high. The results of the analysis record the rapid pace of industrial development in China (currently the 1st place in the world). India is already at the 5th position. The Republic of Korea occupies the 6th position (losing India its 5th place in 2005 and 2010). Brazil ranked 9th. Russia occupied the 13th position in 2019. However, the data on the leading countries on the MVA per capita (at constant prices 2015, USD) varies greatly (for example, Germany -8980 dollars, Japan - 7645 dollars, China - 2864 dollars, India - 315 dollars) (Table 2).
The analysis of the statistical database of the US Science Foundation (at current prices, millions of current dollars) showed that already in 2016 China became the $1^{\text {st }}$ in the world manufacturing industry (28.6\% of global manufacturing value added), ahead of the United States (19.5\%), Japan (7.2\%) and Germany (5.8\%) (Science and Engineering Indicators - 2020). UNIDO show, that the position of China (the "factory of the world) became better now $-29,7 \%, 2019$ at constant prices 2015, US\$ (table 2).

Let us analyze the results of the calculations. It is recorded that the shifts are directed from the West to the East. Gradually, the former leading regions - North America and Europe - are losing their positions. The share of Asia in the world industrial production is growing very rapidly (table 3).

Table 3 - The share of regions in the global manufacturing industry, 2001-2016 (\%)

\begin{tabular}{|l|c|c|c|c|c|c|}
\hline Regions & 2003 & 2006 & 2009 & 2012 & 2015 & 2016 \\
\hline North America & 30,3 & 27,7 & 23,3 & 21,1 & 22,5 & 22,5 \\
\hline Central and South America & 3,4 & 4,8 & 5,8 & 6,2 & 4,7 & 4,0 \\
\hline Europe & 32,4 & 32,1 & 28,8 & 24,4 & 22,8 & 22,5 \\
\hline Africa & 1,0 & 1,0 & 1,1 & 1,2 & 1,2 & 1,1 \\
\hline Asia & 31,7 & 33,2 & 39,9 & 46,0 & 47,9 & 49,0 \\
\hline Oceania & 1,2 & 1,2 & 1,1 & 1,1 & 0,9 & 0,9 \\
\hline
\end{tabular}

Source: Science and Engineering Indicators, 2018, author's calculations.

The calculations showed that now the group of the most "industrial" regions in the world is headed by Asia (about $50 \%, 2016$ ). Its share in the world manufacturing industry is greater than the total share of two regions - Europe and North America (Table 3). The progress, of course, is associated with the rapid economic development of China and India, as well as with the industrial development of Asian 
"newly industrialized countries" (NIC -Republic of Korea, Singapore, Taiwan, Malaysia, Thailand, Indonesia, etc.).

Value-added output of "high R\&D intensive" and "medium-high R\&D intensive" industries. The growth of value-added output of "high $\mathrm{R} \& \mathrm{D}$ intensive" industries is a key trend in the transformation of the spatial structure of the world manufacturing industry. In the analyzed 15 years (from 2003 to 2018), HT manufacturing value added doubled - from \$ 1521 billion to \$ 3242 billion at current dollars (Science and Engineering..., 2020).

The leading region is currently Asia $(39 \%, 2018)$.

This was primarily due to an increase of the share of China in the production of high-tech products (an increase of the share from 6 to 20\%). The North American region moved to the second position with a decrease in the share in the world output from 40 to $34 \%$ in the analyzed period. Europe has the $3 \mathrm{~d}$ position (Table 4).

Table 4 - Value-added output of "high R\&D intensive" industries by selected region (share of regions), 2003-2018, \%

\begin{tabular}{|l|c|c|c|c|c|c|}
\hline Regions & 2003 & 2006 & 2009 & 2012 & 2015 & 2018 \\
\hline North America & 40,5 & 37,9 & 36,7 & 33,1 & 34,6 & 34,0 \\
\hline Central and South America & 1,4 & 2,0 & 2,4 & 2,7 & 2,2 & 1,9 \\
\hline Europe & 28,2 & 28,9 & 28,3 & 25,8 & 23,8 & 23,3 \\
\hline Africa & 0,5 & 0,7 & 0,7 & 0,9 & 0,9 & 0,8 \\
\hline Asia & 28,1 & 29,2 & 30,2 & 35,4 & 37,2 & 38,7 \\
\hline Oceania & 1,2 & 1,4 & 1,5 & 1,9 & 1,3 & 1,4 \\
\hline
\end{tabular}

Source: Science and Engineering Indicators, 2020, author's calculations.

Production volumes continued to grow in all regions. But the growth rates were different. For example, in North America and Europe, production volumes increased 2 times, and in Asia - 3 times (including in China - 7 times).

Nevertheless, at the country level, the USA remains the world leader in "high $R \& D$ intensive" industries (32\% of the world valueadded output). China is rapidly catching up that country. It is important to note that these countries are constantly increasing their influence in the control of high-tech industries in the world market, including as a result due to the development of process of reindustrialization and neoindustrialization.

You can analyze data on the production of goods and services from "high R\&D intensive" industries by selected countries (tabl. 5).

Table 5 - Value-added output of "high R\&D intensive" industries by selected region or country (billions of current dollars and percent share), 2003-2018

\begin{tabular}{|c|c|c|c|c|c|c|c|c|c|c|}
\hline \multirow{2}{*}{ Year } & \multicolumn{2}{|c|}{ United States } & \multicolumn{2}{c|}{ EU } & \multicolumn{2}{c|}{ Japan } & \multicolumn{2}{c|}{ China } & \multicolumn{2}{c|}{ Rest of world } \\
\cline { 2 - 12 } & $\begin{array}{c}\text { Billions } \\
\text { dollars }\end{array}$ & $\begin{array}{c}\text { Share } \\
(\%)\end{array}$ & $\begin{array}{c}\text { Billions } \\
\text { dollars }\end{array}$ & $\begin{array}{c}\text { Share } \\
(\%)\end{array}$ & $\begin{array}{c}\text { Billions } \\
\text { dollars }\end{array}$ & $\begin{array}{c}\text { Share } \\
(\%)\end{array}$ & $\begin{array}{c}\text { Billions } \\
\text { dollars }\end{array}$ & $\begin{array}{c}\text { Share } \\
(\%)\end{array}$ & $\begin{array}{c}\text { Billions } \\
\text { dollars }\end{array}$ & $\begin{array}{c}\text { Share } \\
(\%)\end{array}$ \\
\hline 2003 & 573,4 & 38 & 380,5 & 25 & 190,1 & 12 & 92,1 & 6 & 159,9 & 11 \\
\hline 2006 & 666,8 & 35 & 473,6 & 25 & 189,6 & 10 & 146,8 & 8 & 234,5 & 12 \\
\hline 2009 & 743,7 & 35 & 509,9 & 24 & 191,1 & 9 & 220,5 & 10 & 282,4 & 13 \\
\hline 2012 & 782,9 & 31 & 516,6 & 20 & 199,0 & 8 & 368,1 & 15 & 386,1 & 15 \\
\hline 2015 & 890,8 & 33 & 537,2 & 20 & 146,8 & 5 & 500,0 & 18 & 347,6 & 13 \\
\hline 2018 & 1044,7 & 32 & 619,5 & 19 & 146,2 & 5 & 669,4 & 21 & 386,3 & 12 \\
\hline
\end{tabular}

Source: Science and Engineering Indicators, 2020 
The "high R\&D intensive" industries are: aircraft and spacecraft industry, pharmaceuticals, computer, electronic, and optical products, computer software publishing, scientific R\&D services. The leaders in this branch of the world industry are now: USA, China, Japan, Germany, Republic of Korea, Taiwan, Ireland, UK, and Switzerland. Among the leaders we see Ireland (now called the "Celtic Lion" by analogy with the "Asian Tigers"), which even outstripped of the UK.

The 'medium-high R\&D intensive' industries are: chemicals excluding pharmaceuticals, electrical equipment and other machinery and equipment, motor vehicles, railroads and military vehicles, weapons and ammunition industry, IT services. You can analyze data on the production of goods and services from "medium-high R\&D intensive" industries by selected regions and countries (tabl. 6,7).

Asia is the leader (almost 47\%, 2018). At the same time, we observe a decrease in the share of North America from 29 to 24\%. The leaders of "medium-high R\&D intensive" industries in 2018 were: China (26\%), USA (22\%), Japan (10\%), Germany (8\%), Republic of Korea, India, UK, France and Italy.

You can analyze data on the production of goods and services from "medium-high R\&D intensive" industries by selected countries and regions (tabl. 7).

Table 6 - Value-added output of “medium-high R\&D intensive” industries by selected region (share of regions), 2003-2018, \%

\begin{tabular}{|l|c|c|c|c|c|c|}
\hline Regions & 2003 & 2006 & 2009 & 2012 & 2015 & 2018 \\
\hline North America & 29,0 & 26,2 & 22,0 & 22,0 & 24,1 & 24,1 \\
\hline Central and South America & 2,3 & 3,3 & 4,4 & 4,4 & 3,1 & 2,5 \\
\hline Europe & 34,1 & 34,8 & 31,7 & 27,6 & 26,1 & 25,0 \\
\hline Africa & 0,8 & 1,0 & 1,2 & 1,2 & 1,2 & 1,0 \\
\hline Asia & 32,9 & 33,7 & 39,5 & 43,7 & 44,7 & 46,6 \\
\hline Oceania & 0,9 & 1,0 & 1,2 & 1,2 & 0,9 & 0,8 \\
\hline
\end{tabular}

Source: Science and Engineering Indicators, 2020, author's calculations.

Table 7 - Value-added output of "medium-high R\&D intensive" industries by selected or country or region (billions of current dollars and percent share), 2003-2018

\begin{tabular}{|c|c|c|c|c|c|c|c|c|c|c|}
\hline \multirow{2}{*}{ Year } & \multicolumn{2}{|c|}{ United States } & \multicolumn{2}{|c|}{ EU } & \multicolumn{2}{c|}{ China } & \multicolumn{2}{c|}{ Japan } & \multicolumn{2}{c|}{ Rest of world } \\
\cline { 2 - 13 } & $\begin{array}{c}\text { Billions } \\
\text { dollars }\end{array}$ & $\begin{array}{c}\text { Share } \\
(\%)\end{array}$ & $\begin{array}{c}\text { Billions } \\
\text { dollars }\end{array}$ & $\begin{array}{c}\text { Share } \\
(\%)\end{array}$ & $\begin{array}{c}\text { Billions } \\
\text { dollars }\end{array}$ & $\begin{array}{c}\text { Share } \\
(\%)\end{array}$ & $\begin{array}{c}\text { Billions } \\
\text { dollars }\end{array}$ & $\begin{array}{c}\text { Share } \\
(\%)\end{array}$ & $\begin{array}{c}\text { Billions } \\
\text { dollars }\end{array}$ & $\begin{array}{c}\text { Share } \\
(\%)\end{array}$ \\
\hline 2003 & 600,3 & 25 & 747,2 & 32 & 165,5 & 7 & 437,4 & 19 & 260,5 & 11 \\
\hline 2006 & 684,3 & 23 & 953,0 & 32 & 273,0 & 9 & 478,9 & 16 & 407,0 & 14 \\
\hline 2009 & 659,8 & 19 & 971,2 & 29 & 531,1 & 16 & 493,9 & 15 & 499,0 & 15 \\
\hline 2012 & 869,8 & 19 & 1115,6 & 24 & 907,2 & 20 & 642,9 & 14 & 696,3 & 15 \\
\hline 2015 & 1022,8 & 21 & 1138,6 & 24 & 1144,6 & 24 & 487,6 & 10 & 592,1 & 12 \\
\hline 2018 & 1251,7 & 22 & 1309,1 & 23 & 1515,0 & 26 & 557,7 & 10 & 636,8 & 11 \\
\hline
\end{tabular}

Source: Science and Engineering Indicators, 2020

The balance of power in the global economy and in "medium-high R\&D intensive" industries is changing. The production of China has grown at a very rapid pace over the past decade. The share of China is $26 \%, 2018$. The share of EU is $23 \%$. \%. The share of USA is $22 \%$ (tabl. 7).
The share of regions in the world production of some types of manufacturing industries. It is important to note that Asia has the largest share in all extractive industries (Table 8,9).

The share of Asia in oil production exceeded $40 \%$ of the global volume in 2018 (at a strong 
reduction in the share of North America from 54 to $23 \%$ ). The leaders of oil production in the world are Saudi Arabia, the USA, Russia, Canada, China, Iraq, and Iran. North America's share in natural gas production has also fallen sharply from 93 to $26 \%$ of the world production since 1950 . The share of Asia has grown from 0.4 to $31 \%$. The leaders in natural gas extraction are the USA, Russia, Canada, Iran, Qatar, and China.

In the bauxite mining industry in 1950, the leader was the Central and South America. Foreign Europe was the second. By 2018, the
European countries have virtually stopped mining bauxite (the main raw material for aluminum smelting). Now Asia is leader (about 33\% of the world production). The leaders in the extraction of bauxite are: Australia, China, Guinea, Brazil, India, and Jamaica. The share of Asian countries in the extraction of iron ore (in commercial mass) is more than $25 \%$, etc.

It is important to note that in manufacturing industry there is also a serious redistribution of production between large regions of the world in favor of Asian countries (table 9).

Table 8 - The share of regions in the world mining industry, 1950-2018, \%

\begin{tabular}{|l|c|c|c|c|c|c|c|c|}
\hline \multirow{2}{*}{} & \multicolumn{2}{|c|}{ Crude oil } & \multicolumn{2}{c|}{ Natural gas } & \multicolumn{3}{c|}{ Bauxite } & \multicolumn{3}{c|}{$\begin{array}{c}\text { Iron ore (actual } \\
\text { weight) }\end{array}$} \\
\cline { 2 - 11 } & 1950 & 2018 & 1950 & 2018 & 1950 & 2018 & 1950 & 2018 \\
\hline Europe & 1,9 & 3,6 & 2,6 & 6,5 & 25,5 & 1,2 & 30,3 & 1,8 \\
\hline USSR/CIS & 7,3 & 15,8 & 3,1 & 21,5 & 6,4 & 3,4 & 15,7 & 8,1 \\
\hline North America & 54,0 & 23,0 & 92,8 & 27,2 & 15,8 & 0,1 & 41,0 & 3,9 \\
\hline Central and South America & 17,6 & 7,5 & 1,2 & 4,6 & 43,6 & 15,8 & 2,8 & 21,3 \\
\hline Asia & 18,7 & 41,1 & 0,4 & 30,7 & 7,1 & 32,9 & 2,1 & 40,6 \\
\hline Africa & 0,5 & 8,7 & 0 & 6,1 & 1,6 & 16,6 & 4,5 & 2,6 \\
\hline Oceania & 0 & 0,3 & 0 & 3,4 & 0,0 & 30,0 & 1,0 & 25,3 \\
\hline
\end{tabular}

Sources: BP Statistical Review of World Energy, 2019; Mineral Commodity Summaries, 2019, and other sources of information, author's calculations.

Table 9 - The share of regions in the world manufacturing industries, 1950-2018, \%

\begin{tabular}{|l|c|c|c|c|c|c|c|c|}
\hline \multirow{2}{*}{} & \multicolumn{2}{|c|}{$\begin{array}{c}\text { Electricity } \\
\text { generation }\end{array}$} & \multicolumn{2}{|c|}{ Aluminum } & \multicolumn{3}{c|}{ Steel } & \multicolumn{2}{c|}{ Cars } \\
\cline { 2 - 11 } & 1950 & 2018 & 1950 & 2018 & 1950 & 2018 & 1950 & 2018 \\
\hline Foreign Europe & 31,1 & 15,3 & 52,5 & 8,1 & 31,9 & 9,9 & 13,7 & 22,9 \\
\hline USSR/CIS & 9,3 & 5,3 & 8,0 & 6,7 & 14,4 & 5,7 & 0,8 & 2,5 \\
\hline North America & 47,7 & 20,5 & 28,5 & 8,2 & 48,1 & 6,6 & 85,5 & 7,1 \\
\hline Central and South America & 2,2 & 4,9 & 1,6 & 2,5 & 0,5 & 2,7 & 0 & 3,8 \\
\hline Asia & 6,9 & 48,1 & 5,5 & 68,0 & 4,1 & 74,1 & 0 & 62,8 \\
\hline Africa & 1,6 & 3,2 & 0,7 & 3,0 & 0,4 & 0,8 & 0 & 1,0 \\
\hline Oceania & 1,3 & 1,5 & 3,2 & 3,6 & 0,5 & 0,3 & 0 & 0,2 \\
\hline
\end{tabular}

Sources: World Steel in Figures, 2019; BP Statistical Review of World Energy, 2019; Mineral Commodity Summaries, 2019; International Organization of Motor Vehicle Manufacturers, 2019, and other sources of information, author's calculations. 
The share of Asia in the production of steel smelting - from 4 to $74 \%$ increased; in primary aluminum smelting - from 5.5 to $68 \%$, in production of passenger cars - to $63 \%$; in the production of mineral fertilizers - from 5 to $60 \%$. And the share of Asia increased in 1950-2018 from 8 to $83 \%$ in the production of various types of chemical fibers, etc. All the above data confirm the fact of the leading position of Asia. Moreover, the share of the Asian region continues to grow (Rodionova et al., 2016; Kondrat'ev, 2017; Industrial Statistics..., 2020).

Authors' rating of the countries of the world in terms of industrial development. Many developing economies (China, Republic of Korea, Singapore, Malaysia, Thailand, Mexico, Argentina, Turkey, Brazil, UAE, Kuwait, Qatar, Saudi Arabia and others) have made a decisive progress. They exceed many European countries at the indexes of the industrial development (Global Information ..., 2016; Measuring the Information..., 2017; Global Innovation..., 2018; Industrial Statistics..., 2020).

Author determined the indexes which allow characterizing the level of the industrialization process development in different countries to a high degree of accuracy. Author should point out that there is high positive correlation among the selected indexes. We should note that the highest correlation (about 0.6-0.8) was determined between the ranks of the countries in the authors' rating of the industrial development and GDP per capita, manufacturing value added per capita and "the relative industrialization coefficient". The author's ranking results by the industrialization level of 11 leading countries is shown in the table (tabl. 10).

Table 10 - Position of the countries in the authors' rating list and specific indexes, 2015

\begin{tabular}{|c|l|c|c|c|c|c|c|}
\hline \multicolumn{2}{|c|}{$\begin{array}{c}\text { Author's rating of the level of } \\
\text { industrial development of countries }\end{array}$} & \multicolumn{2}{c|}{$\begin{array}{c}\text { «Relative } \\
\text { industrialization } \\
\text { coefficient» }\end{array}$} & \multicolumn{2}{c|}{ MVA per capita } & \multicolumn{2}{c|}{ GDP (PPP) per capita } \\
\hline position & country & index & position & US \$ & position & $\begin{array}{c}\text { Thousand. of } \\
\text { US \$ }\end{array}$ & position \\
\hline 1 & Republic of Korea & 5.27 & 10 & 7400.20 & 8 & 37.9 & 25 \\
\hline 2 & Singapore & 6.98 & 4 & 9292.00 & 3 & 87.1 & 3 \\
\hline 3 & Ireland & 10.28 & 1 & 10739.40 & 2 & 69.4 & 5 \\
\hline 4 & Switzerland & 8.22 & 2 & 14466.60 & 1 & 59.4 & 8 \\
\hline 5 & Germany & 5.82 & 8 & 9193.00 & 4 & 48.2 & 15 \\
\hline 6 & Czech Republic & 3.12 & 20 & 5011.90 & 16 & 33.2 & 31 \\
\hline 7 & Malaysia & 1.41 & 38 & 2490.90 & 36 & 27.2 & 39 \\
\hline 8 & Japan & 6.59 & 5 & 8382.30 & 5 & 38.9 & 24 \\
\hline 9 & Austria & 6.13 & 7 & 8335.70 & 6 & 47.9 & 16 \\
\hline 10 & Slovenia & 2.90 & 23 & 4328.30 & 21 & 32,0 & 32 \\
\hline 11 & China & 0.93 & 48 & 2025.30 & 38 & 15.4 & 61 \\
\hline
\end{tabular}

The highest positions in the author's ranking of «the level of industrialization» are: Ireland, Switzerland, Singapore, Japan, Finland, Austria, Germany, Sweden, the Republic of Korea, and Denmark. It is important also that China holds the 3rd position in the UNIDO rating table (Competitive Industrial Performance 2019 - CIP Index). The leaders by CIP Index are Germany and Japan. Republic of Korea, the USA and Ireland follow China. It is implied that the tendencies of manufacturing development ensure the long-term growth of the entire country economy (Industrial..., 2016; Competitive Industrial..., 2020).

\section{Discussion}

The industrialized economies remain in the leaders group of all international rating tables 
(inclusive author's rating). It should also consider the following. At the same time, many economically highly developed countries are currently pursuing their strategies in the direction of restoring the role of industrial production (reindustrialization, neoindustrialization). According to our strong opinion when calculating the industrialization integrated index you should consider participation of the countries in the world gross value chains (GVC) (Draper, 2013). For example, project World Input-Output Database (WIOD) (World InputOutput Database, 2019) is as an attempt to evaluate the contribution of the countries to the world gross value chains. This, obviously, will have an impact on the countries order in the compiled ratings.

The international statistics shows decrease in the share of the manufacturing industry in GDP of the developed countries. However, it does not mean the decrease in the level of the industry development of these states. This fact for the developed countries can be partially explained by "invisibility" of their real participation in the global added value chains (Kondrat'ev, 2014; Shvab, 2017). New digital evolutions in industry offer key opportunities for companies (Digital Transformation..., 2017). The digital restructuring of industry offers plenty of opportunities to boost international competitiveness. Without any doubt, transfer of the industrial production to China, Singapore, Malaysia, Thailand and other developing countries allows receiving additional benefits, mainly for the transnational corporations. WIOD project showed that the data on the share of China in the high technology export may be exaggerated (Draper, 2013; World InputOutput Database - WIOD, 2019). For example, some Chinese researchers note that $82 \%$ of China's high-tech exports are high-tech products made from imported key parts and components. And trade statistics mistakenly attribute to China the entire value of these harvested goods, thereby greatly inflating the value of Chinese exports (Yuqing, 2011). Nevertheless, in accordance with the existing methodology, the international statistics reflects a total value of the whole product as Chinese high technology export.

\section{Conclusions}

A great number of conditions and factors, including new ones (the development of information and communication technologies and the network economy, interstate integration, the geographic strategy of TNCs, etc.) influence on the placement of manufacturing industries.

Economically developed countries (USA, Japan, EU countries) retain their important positions in the global industry. In order to characterize the industry of this group of industrialized states, the term "highly developed postindustrial industry" is used.

The population of developing countries is growing. And the volumes of the production and consumption of products in these states are growing as well. The growing importance of developing countries in the world economy is recorded. The main direction of the current stage of development of the industrialization process in the world is the shift of production and consumption to Asia. Asia is the region-leader in the world industry. Now the world industrial leader is China. We can note the differentiation process of the developing countries. But a major part of the developing countries (particularly, African) still represents the outsiders of the world industry. The results of the author's ranking prove this thesis.

It is the fact that the process of industrialization is continuing at the global level. But it occurs under different conditions, by different ways and at different rates. But the global pandemic (COVID-19) has affected the course of world history, as well as the volume of production and the balance of power in the world economy. And this factor will continue to influence the global situation in the world for a long time to come.

\section{References}

BP The Statistical Review of World Energy (2019). Available from: https://www.bp.com/en/global/corporate/news-andinsights/speeches/bp-statistical-review-of-world-energy-2018.html

Crescenzi R., Rodriguez-Pose A. (2011). Innovation and Regional Growth in the European Union. Advances in Spatial Science. Springer-Verlag Berlin Heidelberg.

Competitive Industrial Performance Report (2020). CIP Index, edition 2020: Country and Economy Profiles. United Nations Industrial Development Organization. Vienna, 2020. dem/

Digital Transformation Monitor Germany: Industrie 4.0 (2017). Available from: https://ec.europa.eu/growth/tools-databases/ 
Draper P. (2013). The Shifting Geography of Global Value Chains: Implications for Developing Countries, Trade Policy, and the G20. DOI: $10.7871 / 2291-4110.1005$

Gierańczyk W. (2010). Development of High Technologies as an Indicator of Modern Industry in the EU. Bulletin of Geography. Socio-economic Series, 14: 23-35. Available from: http://www.bulletinofgeography.umk.pl/14_2010/02_Gieranczyk.pdf

Gieranczyk, W., Ryczkowski, M. (2018). Public Statistics Resources as a Source for Research in Geography of Industry. Studies of the industrial geography commission of the polish geographical society, 32 (4): 240-251.

Global Manufacturing Competitiveness Index (2016). Available from: http://avraska.com.tr/Dokumanlar/Global-ManufacturingCompetitiveness-2016.pdf

Grinberg R. (2016). Poiski novyh ekonomicheskih modelej kak otvet na vyzovy 21 veka [The search for new economic models as a response to the challenges of the 21 st century]. Geografiya mirovogo razvitiya (Proceedings), 3. In.: L. Sincerova (eds). Moscow: Tovarishchestvo nauchnyh izdanij KMK, 8-15 (In. Russ.)

Industrial Development Report (2016). The Role of Technology and Innovation in Inclusive and Sustainable Industrial Development. UNIDO. Vienna.

Industrial Development Report (2020). Industrializing in the digital age. UNIDO. Vienna, 2020.

Industrial Statistics Database (2020). UNIDO. INDSTAT4. Available from: https://stat.unido.org/database/MVA\%202020,\%20 Manufacturing

International Organization of Motor Vehicle Manufacturers (2019). Available from:: http://www.oica.net

Kilar W. (2018). Corporations as an Object of Research in Geography of Industry. Studies of the industrial geography commission of the polish geographical society, 32 (4): 69-85.

Kokuytseva T.V., Rodionova I.A., Damnjanovic V. (2019) Preconditions for the transition of developed and developing countries to the cyber economy through the process of digital modernization. The Cyber economy. Opportunities and Challenges for Artificial Intelligance in the Digital Workplace. Ed. V.Filippov, A.Chursin, J.Ragulina, E.Popkova. Contributions to Economics. Springer Nature. Switzerland, 2019: 51-59.

Kondrat'ev V.B. (2017) Global'nyye tsepochki sozdaniya stoimosti kak forma transnatsionalizatsii otrasli [Global value chains as a form of industry transnationalization]. Problemy teorii i praktiki upravleniya = Problems of Management Theory and Practice, 2017, no. 6: 8-20. (In Russ.)

Kourtit, K. et al. (2011). Drivers of Innovation, Entrepreneurship and Regional Dynamics. In.: Kourtit, K., Nijkamp, P., Stough, R. (Eds.). Advances in Spatial Science. Berlin Heidelberg: Springer-Verlag.

Mineral Commodity Summaries (2019). U.S. Department of the Interior. U.S. Geological Survey. Available from: https://prdwret.s3-us-west-2.amazonaws.com/assets/palladium/production/atoms/files/mcs2019_all.pdf

Rodionova I., Kokuytseva T., Semenov A. (2016). Features of migration processes in different world industries in the second half of the XX century. Journal of Applied Economic Sciences, XI, 8 (46): 1769-1780. Available from: http://www.cesmaa.eu/ journals/jaes/files/JAES\%20Winter\%208(46)_online_last.pdf

Science and Engineering Indicators (2018). Appendix (tables 6). Two volumes. Arlington, VA: National Science Foundation, USA. Available from: http://nsf.gov

Science and Engineering Indicators (2020). he State of U.S. Science and Engineering 2020. Production and Trade of Knowledgeand Technology-Intensive Industries. National Science Foundation. National Science Board. National Center for Science and Engineering Statistics (NCSES). Alexandria, VA. Available from: http://nsf.gov

Shvab K. (2017). Chetvyortaya promyshlennaya revolyuciya [Fourth industrial revolution]. Moscow: Eksmo. 285 p. (In. Russ.)

The Global Information Technology Report (2016). World Economic Forum. Available from: https://www.wsj.com/public/ resources/documents/GITR2016.pdf

The Global Innovation Index (2018). Energizing the World with Innovation. INSEAD (The Business School for the World) and the World Intellectual Property Organization. Available from: https://www.wipo.int/edocs/pubdocs/en/wipo_pub_gii_2018.pdf

Measuring the Information Society Report (2017). The ICT Development Index. Available from: https://www.itu.int/net4/ ITU-D/idi/2017/index.html

Tolkachev S. (2015). Dve modeli neoindustrializzacii [Two models of neo-industrialization] Ekonomist, 11: 13-23 (In. Russ.)

Varnavsky V.G. (2019). Transformatsiya mirovogo geoekonomicheskogo prostranstva $\mathrm{v}$ usloviyakh reindustrializatsii [Transformation of the world geo-economic space in the context of reindustrialization]. Bulletin of the Institute of Economics of the Russian Academy of Sciences. - 2019. - No. 2. - P. 119-133. DOI: 10.24411 / 2073-6487-2019-10022.

World Input-Output Database. Retrieved from: http://www.wiod.org/home

World Steel Association (2019). World Steel in Figures. Retrieved from: http://www.worldsteel.org

Yuqing X. (2011). China's High-Tech Exports: The Myth and Reality. Asian Economic Papers13(1) DOI: 10.2139/ssrn.1865013

Ziolo Z. (2017). Impact of Industry and Services on Socio-Economic Development of Spatial Systems. Studies of the industrial geography commission of the polish geographical society, 31 (4): 7-24. 